\title{
The Impedance Analysis of Reaction Kinetics at the Interface between Molten Sn-S Alloy and $\mathrm{ZnCl}_{2}-\mathrm{NaCl}$ Salt
}

\author{
Shulan WANG, Guangqiang LI and Zhitong SUI
}

School of Materials and Metallurgy, Northeastern University, P. O. Box 119, Shenyang, 110006, P. R. China.

(Received on January 19, 1998; accepted in final form on March 25, 1998)

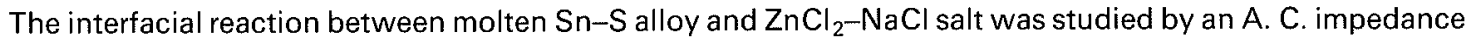
method to clarify the individual kinetic factors concerning the electrode reaction at the interface between the alloy and the salt. The total impedance between $\mathrm{Sn}-\mathrm{S}$ alloy and $\mathrm{ZnCl}_{2}-\mathrm{NaCl}$ salt was measured.

The results obtained were successfully used to determine the individual kinetic factors on electrode reaction between the alloy and the salt, such as electrolyte resistance $R_{\mathrm{e}}$, double-layer capacitance $C_{\mathrm{d}}$, charge transfer resistance $R_{\mathrm{ct}}$, rate constant of desulfurization reaction $k_{\mathrm{f}}$ and so on. When overpotential $\eta$ equals to $-85 \mathrm{mV}$, these values are as follows: $R_{\mathrm{e}}=2.93 \times 10^{-5} \Omega \mathrm{m}^{2}, R_{\mathrm{ct}}=2.47 \times 10^{-5} \Omega \mathrm{m}^{2}, C_{\mathrm{d}}=1.01 \mathrm{Fm}^{-2}, k_{\mathrm{f}}=2.1 \times 10^{-3} \mathrm{~s}^{-1}$.
\end{abstract}

KEY WORDS: A. C. impedance method; polarization; equivalent-circuit; double-layer capacitance; chargetransfer resistance; salt-metal interfacial reaction.

\section{Introduction}

The desulfurization reaction at the interface between slag and metal is one of the most important reactions in iron and steel making. It is a complicated coupling reaction consisting of several steps. The conventional method of kinetic investigation is based on experiments, which depend mainly on chemical analysis for the quenched samples. ${ }^{1-3}$ ) Owing to the ionic nature of molten slag, the interfacial reaction kinetics can also be studied electrochemically. The A. C. impedance method is an electrochemical method, which can be used in the studies of ionic conductor, semiconductor and dielectric materials in solid or liquid state, especially suitable for systems with coupling reactions. ${ }^{4)}$ Many investigations have been done on the aqua-solution. ${ }^{5-7)}$ But unfortunately there only one is on the system of $\mathrm{Pt} / \mathrm{CaO}-$ $\mathrm{SiO}_{2}-\mathrm{Al}_{2} \mathrm{O}_{3}{ }^{8)}$ in the field of molten metal and slag. It has not been found for the investigation of $\mathrm{Sn}-\mathrm{S} / \mathrm{ZnCl}_{2}-$ $\mathrm{NaCl}$ system.

The A. C. impedance method was applied to the desulfurization reaction at the interface between molten $\mathrm{Sn}-\mathrm{S}$ alloy and $\mathrm{ZnCl}_{2}-\mathrm{NaCl}$ salt in order to obtain kinetic parameters electrochemically. The reason why $\mathrm{ZnCl}_{2}-\mathrm{NaCl} / \mathrm{Sn}-\mathrm{S}$ system was chosen for the study of the impedance was to imitate desulfurization condition in iron and steel-making process.

\section{Experimental}

\subsection{Experimental Apparatus}

The schematic diagram of the cell for impedance measurement is shown in Fig. 1. An end-closed glass tube having an inner tube in its bottom was used to contain the $\mathrm{Sn}-\mathrm{S}$ alloy and $\mathrm{ZnCl}_{2}-\mathrm{NaCl}$ molten salt. The $\mathrm{Sn}-\mathrm{S}$ alloy was put in the inner tube. The quantity of $\mathrm{Sn}-\mathrm{S}$ was selected so that the $\mathrm{ZnCl}_{2}-\mathrm{NaCl} / \mathrm{Sn}-\mathrm{S}$ interface could be located in the inner tube. This interface functioned as working electrode (WE), a platinum wire positioned in the bottom of the inner tube was used as WE lead wire, a Pt plate $(0.023 \mathrm{~m} \times 0.009 \mathrm{~m})$ was used as reference electrode 1 (RE1), therefore it has a small resistance and large capacitance. ${ }^{9)} \mathrm{A} \mathrm{Zn}$ plate $(0.23 \mathrm{~m} \times$ $0.02 \mathrm{~m}$ ) was inserted into the $\mathrm{ZnCl}_{2}-\mathrm{NaCl}$ salt as counter electrode (CE). Another reference electrode RE2 was connected with WE. The cell was shielded by a stainless steel tube, which was inserted between heating elements and the cell to prevent noise from the surroundings. All of the lead wires used were shielded and earthed. The

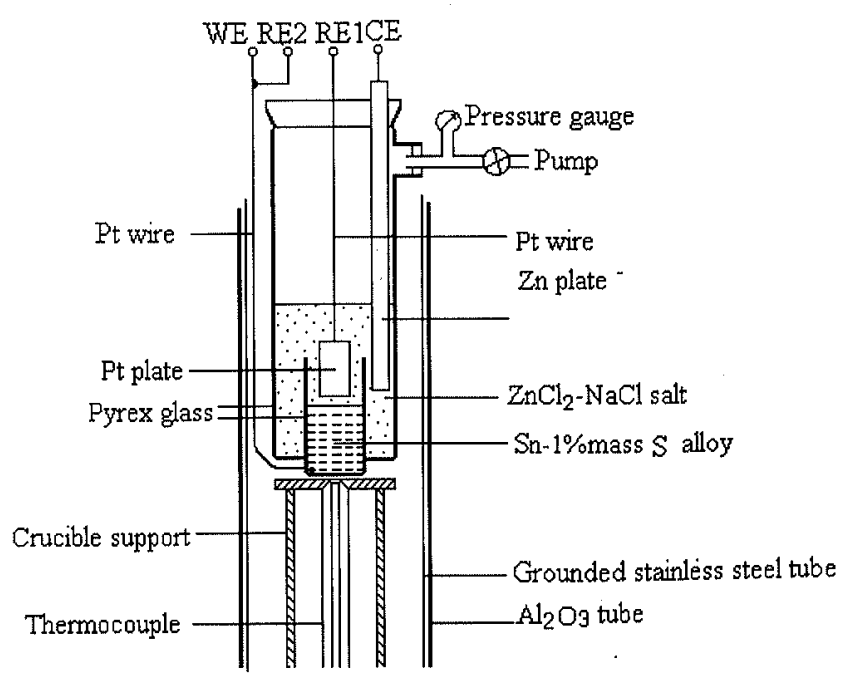

Fig. 1. Cell arrangement for impedance measurement. 
cell was heated by a vertical electric resistance furnace. The experimental temperature was controlled at $603 \pm$ $1 \mathrm{~K}$ using a programmable controller through an $\mathrm{S}$ type thermocouple.

$\mathrm{Sn}-\mathrm{S}$ mother alloy was prepared in Ar atmosphere and was added into molten $\mathrm{Sn}$ to obtain $\mathrm{Sn}-1 \mathrm{mass} \% \mathrm{~S}$ alloy. $\mathrm{ZnCl}_{2}(99.9 \%)$ and $\mathrm{NaCl}(99.9 \%)$ powders were vacuumly dried at $120^{\circ} \mathrm{C}$ for $36 \mathrm{~h}$ and $200^{\circ} \mathrm{C} 24 \mathrm{~h}$ respectively. The weight of the $\mathrm{Sn}-\mathrm{S}$ alloy was $8 \mathrm{~g}$ and that of the $\mathrm{ZnCl}_{2}-\mathrm{NaCl}\left(\mathrm{ZnCl}_{2}: \mathrm{NaCl}=60: 40\right.$ in $\left.\mathrm{mol} \%\right)$ salt was $107 \mathrm{~g}$. The alloy was put in the bottom of the WE tube as shown in Fig. 1, the salt was filled along the sidewall of the cell from the opening. Then the cell was evacuated and filled with purified Ar to remove the air, this operation was repeated three times. After that the glass tube was filled with $\mathrm{Ar}$ and heated up to $603 \mathrm{~K}$. The pressure of $\mathrm{Ar}$ in the glass tube was kept in $1.013 \times 10^{5} \mathrm{~Pa}$. The equilibrium potential of the WE against the $C E$ was monitored until it kept at a stable value, this value is $0.212 \mathrm{~V}$ when WE was as cathode. The cell reaction is:

$$
\begin{array}{ll}
\text { Anode }(\mathrm{CE}) & \mathrm{Zn}=\mathrm{Zn}^{2+}+2 \mathrm{e} \\
\text { Cathode }(\mathrm{WE}) & {[\mathrm{S}]+2 \mathrm{e}=\left(\mathrm{S}^{2-}\right)} \\
\text { Cell reaction: } & \mathrm{Zn}+[\mathrm{S}]=\left(\mathrm{S}^{2-}\right)+\mathrm{Zn}^{2+}
\end{array}
$$

\subsection{Experimental Procedure}

The four electrode cell described above was connected to a solartron 1286 potentiostat which controlled the potential between RE1 and RE2 by passing the required current through WE and CE. First the cathodic polarization curve of WE against RE1 was measured by potentiostatic method. Then the impedance between WE (RE2) and RE1 was measured by applying an A. C. signal with amplitude of $5 \mathrm{mV}$ using the solartron 1255 frequency response analyser. The range of frequency sweeping is from $5 \mathrm{~Hz}$ to $60 \mathrm{kHz}$.

After the experiment, it was found that the thickness of the $\mathrm{Zn}$ plate as $\mathrm{CE}$ was $1 \times 10^{-4} \mathrm{~m}$ thinner than that before. This phenomenon confirmed the above cell reaction (1).

\section{Results and Discussions}

Figure 2 shows the experimental results of polarization curve observed in the system of $\mathrm{Sn}-1 \mathrm{mass} \% \mathrm{~S} / \mathrm{ZnCl}_{2}-$ $\mathrm{NaCl}$ by means of a potentiostatic method. The values on the axis of abscissa are the overpotential which is corrected by reducing the IR drop due to electrolyte resistance of salt from the potential applied between WE against the RE1.

Figure 3 shows the impedance loci observed in the system. There are two relaxation processes in each impedance lotus.

Impedance can be expressed as a complex form:

$$
Z=Z^{\prime}+j Z^{\prime \prime}
$$

where $Z^{\prime}$ and $Z^{\prime \prime}$ are the real and imaginary part of complex impedance $Z$ respectively, they are the functions of frequency, and $j=(-1)^{1 / 2}$. The impedance spectra can be simulated by using some equivalent circuits. The well known Randles circuit is used to explain the

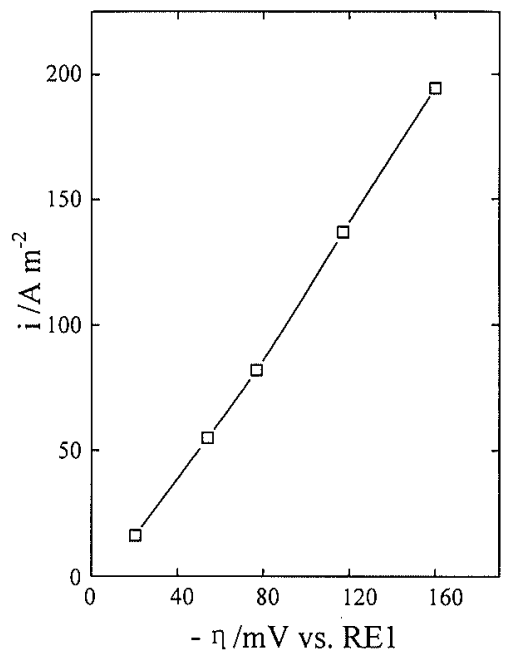

Fig. 2. Cathodic polarization curve for $\mathrm{Sn}-1$ mass $\% \mathrm{~S} / \mathrm{ZnCl}_{2}-$ $\mathrm{NaCl}\left(\mathrm{ZnCl}_{2}: \mathrm{NaCl}=60: 40\right.$ in mol\%) electrode at $603 \mathrm{~K}$.

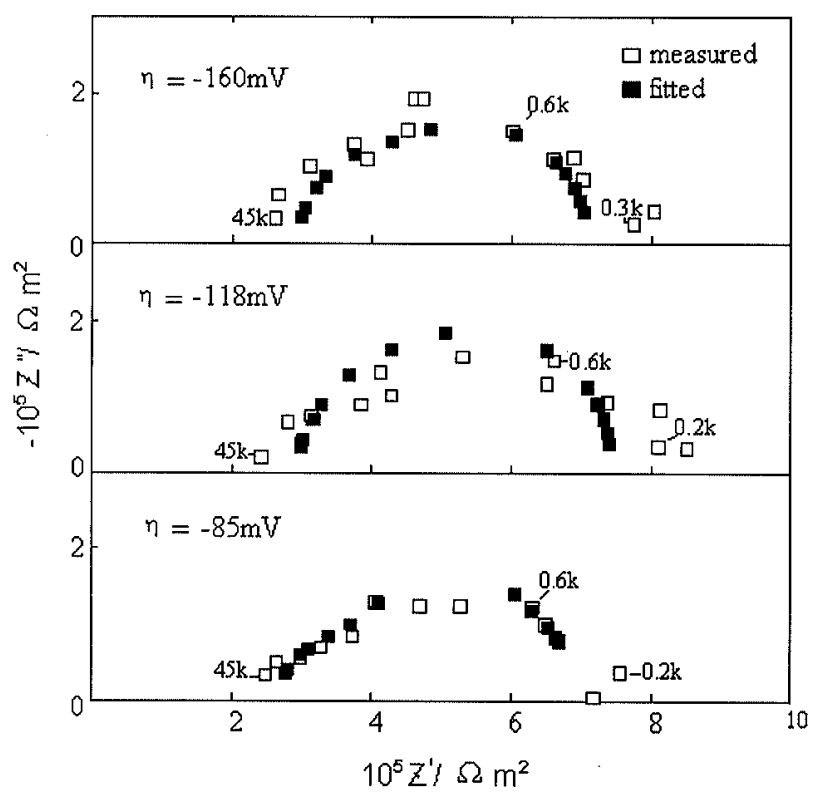

Fig. 3. Complex impedance plots for $\mathrm{Sn}-1$ mass $\% \mathrm{~S} / \mathrm{ZnCl}_{2}$ $\mathrm{NaCl}\left(\mathrm{ZnCl}_{2}: \mathrm{NaCl}=60: 40 \mathrm{in} \mathrm{mol} \%\right)$ system at $603 \mathrm{~K}$ Numbers near the data points are frequency in $\mathrm{kHz}$.

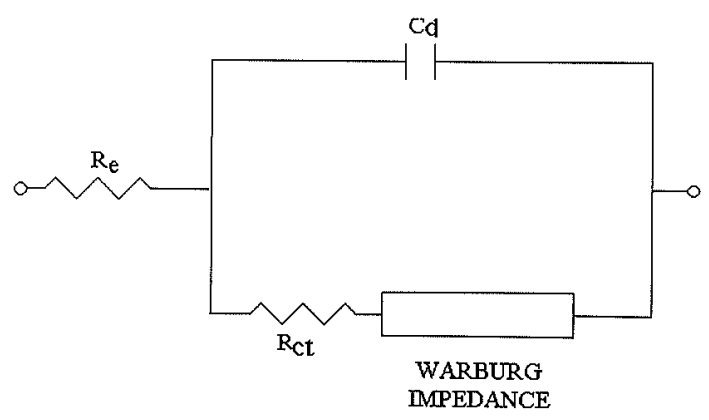

Fig. 4. Randles equivalent circuit.

impedance spectrum obtained in the present work. As shown in Fig. 4, the Randles equivalent circuit is composed of four elements:

$R_{\mathrm{e}}$ : electrolyte resistance, here it stands for electrolyte resistance between $\mathrm{RE} 1$ and the interface of $\mathrm{Sn}-\mathrm{S} / \mathrm{ZnCl}_{2}-\mathrm{NaCl}$; 
ISIJ International, Vol. 38 (1998), No. 8

Table 1. Kinetic parameters for $\mathrm{Sn}-\mathrm{S} / \mathrm{ZnCl}_{2}-\mathrm{NaCl}$ system at $603 \mathrm{~K}$.

\begin{tabular}{|c|c|c|c|c|c|}
\hline$-\eta / \mathrm{mV}$ & $10^{5} \mathrm{R}_{\mathrm{e}} / \Omega \mathrm{m}^{2}$ & $10^{5} \mathrm{R}_{\mathrm{ct}} / \Omega \mathrm{m}^{2}$ & $\mathrm{C}_{\mathrm{d}} / \mathrm{F} \mathrm{m}^{-2}$ & $10^{4} \tau / \mathrm{s}$ & $10^{3} \mathrm{k}_{\mathrm{f}} / \mathrm{s}^{-1}$ \\
\hline 85 & $2.94 \pm 7.5810^{-3}$ & $2.47 \pm 8.6810^{-3}$ & $1.01 \pm 1.7810^{-3}$ & $2.97 \pm 1.3310^{-2}$ & 2.1 \\
\hline 118 & $2.93 \pm 6.1810^{-5}$ & $1.96 \pm 6.3710^{-4}$ & $0.95 \pm 2.3310^{-4}$ & $2.34 \pm 3.4710^{-4}$ & 3.8 \\
\hline 160 & $2.68 \pm 2.0610^{-3}$ & $0.95 \pm 1.0010^{-2}$ & $0.93 \pm 8.8510^{-3}$ & $1.68 \pm 7.7510^{-3}$ & 6.0 \\
\hline
\end{tabular}

Where $\tau=\delta_{N}{ }^{2} / D_{0}$

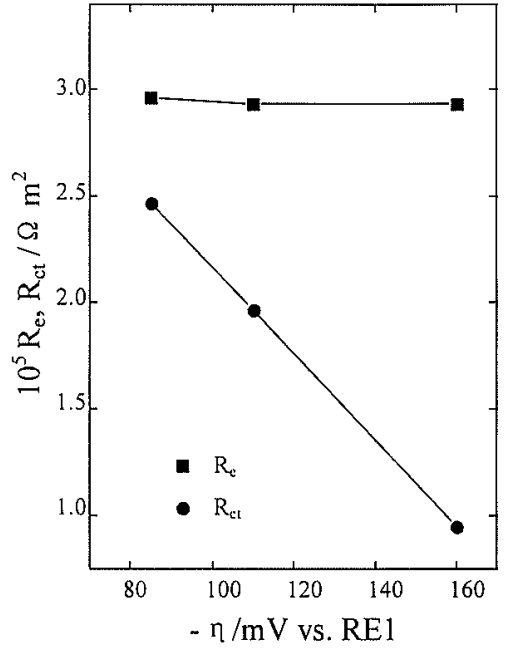

Fig. 5. Overpotential dependence of $R_{\mathrm{c}}$ and $R_{\mathrm{cl}}$ for $\mathrm{Sn}-$ $1 \mathrm{mass} \% \mathrm{~S} / \mathrm{ZnCl}_{2}-\mathrm{NaCl} \quad\left(\mathrm{ZnCl}_{2}: \mathrm{NaCl}=60: 40 \quad\right.$ in $\mathrm{mol} \%$ ) system at $603 \mathrm{~K}$.

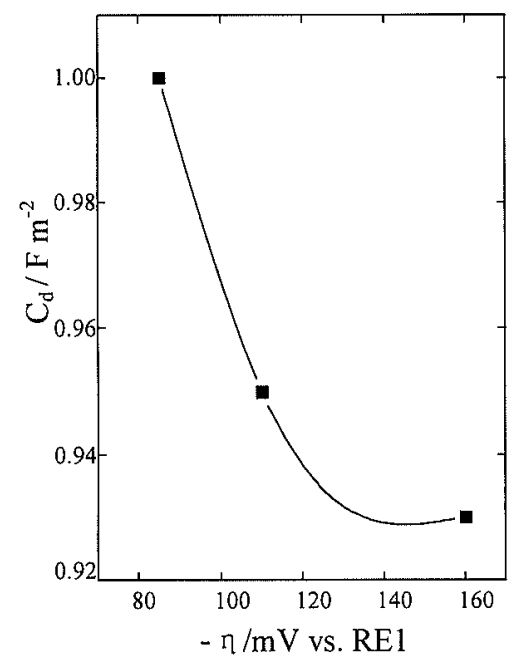

Fig. 6. Overpotential dependence of $C_{\mathrm{d}}$ for $\mathrm{Sn}-1 \mathrm{mass} \% \mathrm{~S} /$ $\mathrm{ZnCl}_{2}-\mathrm{NaCl}\left(\mathrm{ZnCl}_{2}: \mathrm{NaCl}=60: 40\right.$ in $\left.\mathrm{mol} \%\right)$ system at $603 \mathrm{~K}$.

$R_{\mathrm{ct}}:$ charge transfer resistance of reaction: $[\mathrm{S}]+2 \mathrm{e}=$ $\mathrm{S}^{2-}$;

$C_{\mathrm{d}}$ : double layer capacitance;

Warburg impedance: diffusion resistance. In the case of finite diffusion layer, it can be expressed as ${ }^{9)}$ :

$$
Z(\omega)=R_{\mathrm{ct}}\left\{1+\left(k_{\mathrm{f}} t h \delta_{\mathrm{N}}\left(j \omega / D_{0}\right)^{1 / 2}\right) /\left(j \omega D_{0}\right)^{1 / 2}\right\}
$$

$\delta_{\mathrm{N}}$ and $D_{0}$ are thickness of Nernst' layer and diffusion coefficient of $\mathrm{S}$ in molten Sn. Equation (3) can also be expressed as

$$
Z(\omega)-R_{\mathrm{cl}}=R^{*}\left(1+x^{2} / 6\right) /\left(1+x^{2} / 2\right)
$$

where $R^{*}=R_{\mathrm{ct}} k_{\mathrm{f}} \delta_{\mathrm{N}} / D_{0}, x=\delta_{\mathrm{N}}\left(j \omega / D_{0}\right)^{1 / 2}, k_{\mathrm{f}}$ is rate con-

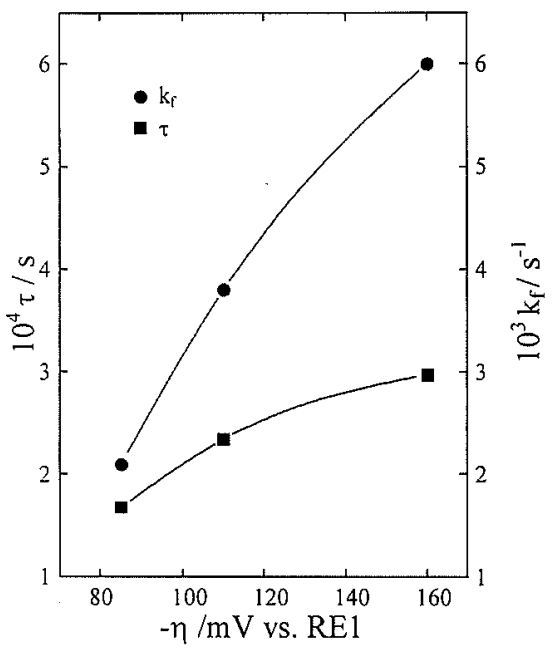

Fig. 7. Overpotential dependence of $k_{\mathrm{f}}$ and $\tau$ for the reaction $[\mathrm{S}]+2 \mathrm{e}=\left(\mathrm{S}^{2-}\right)$ in $\mathrm{Sn}-1 \mathrm{mass} \% \mathrm{~S} / \mathrm{ZnCl}_{2}-\mathrm{NaCl}\left(\mathrm{ZnCl}_{2}\right.$ $\mathrm{NaCl}=60: 40 \mathrm{in} \mathrm{mol} \%$ ) system at $603 \mathrm{~K}$.

stant of desulfurization reaction.

The LEVM impedance analyzing program was used for the complex nonlinear least square fitting. The values of the circuit parameters obtained are listed in Table 1 along with relative standard deviation. Generally, the diffusion coefficient of sulfur in liquid metal is about $10^{-9} \mathrm{~m}^{2} \mathrm{~S}^{-1},{ }^{10)} \delta_{\mathrm{N}}$ can be calculated from $\tau=\delta_{\mathrm{N}}{ }^{2} / D_{0}$ and so can $k_{\mathrm{f}}$ from $R^{*}$. These results are also listed in Table 1. Figures 5, 6 and 7 show the overpotential dependence of the individual kinetic factors in this system. $R_{\mathrm{ct}}$ and $C_{\mathrm{d}}$ increase with the increasing of the overpotential, $k_{\mathrm{f}}$ decreases with that. Electrolyte resistance in $\mathrm{ZnCl}_{2}-\mathrm{NaCl}\left(\mathrm{ZnCl}_{2}: \mathrm{NaCl}=60: 40 \mathrm{~mol} \%\right)$ system at $603 \mathrm{~K}$ is about $0.25 \Omega$. The conductivity of the electrolyte can be calculated using the cell constant determined by standard $\mathrm{KCl}$ aqueous solution, is $1.4 \times$ $10^{-2} \Omega^{-1} \mathrm{~m}^{-1}$. It is in good agreement with the value of $2.0 \times 10^{-2} \Omega^{-1} \mathrm{~m}^{-1}(773 \mathrm{~K})$ in Ref. 11$)$. According to kinetic theories for heterogeneous reaction, rate constant of diffusion process $k_{\mathrm{D}}=D_{0} A / \delta_{\mathrm{N}} V, A$ and $V$ are the area of $\mathrm{WE}$ and electrolyte volume respectively. In this experiment, $A=7.9 \times 10^{-5} \mathrm{~m}^{2}, V=7.9 \times 10^{-7} \mathrm{~m}^{3}, D_{0}$ is about $10^{-9} \mathrm{~m}^{2} \mathrm{~s}^{-1}$ and $\delta_{\mathrm{N}}$ about $0.5 \times 10^{-6} \mathrm{~m}$, then $k_{\mathrm{D}}$ is about 0.2 and $k_{\mathrm{D}} \gg k_{\mathrm{f}}$, therefore the rate control step of desulfurization reaction in this system is electrochemical reaction process.

\section{Conclusions}

A. C. impedance method was used to investigate the interfacial reaction between molten $\mathrm{Sn}-1 \mathrm{mass} \% \mathrm{~S}$ alloy and $\mathrm{ZnCl}_{2}-\mathrm{NaCl}\left(\mathrm{ZnCl}_{2}: \mathrm{NaCl}=60: 40 \mathrm{~mol} \%\right)$ salt. Randles circuit was used to simulate the system. Elec- 
trolyte resistance $R_{\mathrm{c}}$, charge transfer resistance $R_{\mathrm{ct}}$, double-layer capacitance $C_{\mathrm{d}}$, and rate constant of desulfurization reaction $k_{\mathrm{f}}$ concerning this system were obtained by complex nonlinear least square fitting to the parameters of the equivalent circuit. Following could be concluded:

(1) A. C. impedance method is very useful for the study of interfacial reaction in the salt/metal system.

(2) The rate constant of the reaction: $[\mathrm{S}]+2 \mathrm{e}=\left(\mathrm{S}^{2-}\right)$ in $\mathrm{Sn}-1 \mathrm{mass} \% \mathrm{~S} / \mathrm{ZnCl}_{2}-\mathrm{NaCl}$ system was obtained as $k_{\mathrm{f}}=2.1 \times 10^{-3} \mathrm{~s}^{-1}$ in the case of $\eta=-85 \mathrm{mV}$.

(3) The rate controlling step in this system is electrochemical reaction process.

\section{Acknowledgement}

The authors wish to thank "the National Natural Science Foundation of China" for financial supports.

\section{REFERENCES}

1) Xu Chushao and Tang Xin: ISIJ Int., 32 (1992), 1081.

2) Jiang Guochang, Xu Dikuang, Deng Jianxong, Guo Zhancheng and Guan Yulong: Acta Meiall. Sin., 26 (1990), 33.

3) Yan Yuzhang and Lan Hong: Acta Metall. Sin., 27B (1991), 224.

4) J. Ross Macdonald: Applications of Impedance Spectroscopy, A Wiley-Interscience Publication, John Wiley \& Sons, New York (1987), Ch. 1.

5) C. Deslouis and B. Tribollet: Electrochim. Acta, 23 (1978), 935.

6) R. de Levie and D. Vukadin: J. Electroanal. Chem., 62 (1975) 95.

7) J. R. Sandifer and R. P. Buck: J. Electroanal. Chem., 56 (1974), 385.

8) M. Hino and S. Banya: Proc. 2nd Int. Symp. on Metall. Slags and Fluxes, ed. by H. A. Fine and D. R. Gaskell, TMS of AIME, Warrendale, (1984), 669.

9) Claude Gabrielli: Identification of Electrochemical Processes by Frequency Response Analysis, Technical Report Number 04/83, Solartron Instruments, 2 (1984), 25.

10) Y. Ono and S. Ishitobi: Tetsu-to-Hagané, 60 (1974), 1533.

11) N. V. Khodov, V. M. Alkatsev and L. A. Danilin: Tszetnaya Metaplugiya, 4 (1987), 113. 